\title{
IN MEMORY OF LORD COOKE
}

It is a great honour to introduce this special issue of the Victoria University of Wellington Law Review. This issue celebrates the life of one of New Zealand's finest jurists. The range of articles in this issue exemplifies the wide range of interests Lord Cooke had and his ability to frame the most complicated issues in basic principles.

Tony Smith paints a comprehensive biographical picture of Lord Cooke's life as a lawyer. ${ }^{1}$ The reader will enjoy following the young Robin Cooke to Cambridge and learning about his career progression in New Zealand's legal profession, ending as the President of the Court of Appeal, and his life long love for literature and many things English and New Zealand. Lord Cooke was entirely at home at Westminster in the House of Lords, in Cambridge or Oxford, at Inner Temple and in the members' pavilion at Lords. But equally too, summer at the bach on the shores of Lake Taupo or the members' stand of the Basin Reserve were favoured haunts. This New Zealand side of Lord Cooke is brought out by the eulogies of the current Chief Justice, Dame Sian Elias, ${ }^{2}$ Lord Cooke's long time friend from the bench, Sir Michael Hardie Boys, ${ }^{3}$ and his son Francis Cooke QC's very personal tribute. ${ }^{4}$

Dean Knight honours Lord Cooke's contribution in the area of administrative law. He describes the great legacy Lord Cooke has left behind in that area: a simple, fair and discretionary timehonoured tripartite format of administrative law. ${ }^{5}$ The same theme emerges from Elisabeth McDonald's analysis of Lord Cooke's impact on the development of the exceptions to the rule against hearsay and the implementation of his call of "straight to basics" in the Evidence Act $2006 .{ }^{6}$ Susy Frankel discusses Lord Cooke's legacy in patent law where, she observes, Lord Cooke left us with a valuable lesson that the legislature has an important role in delineating the economic and social policy concerns of developing science and technology and how the patent system responds to that. $^{7}$

1 ATH Smith "Lord Cooke and Cambridge" (2008) 39 VUWLR 27.

2 Dame Sian Elias "Eulogy for the Lord Cooke of Thorndon" (2008) 39 VUWLR 1.

3 Sir Michael Hardie Boys "The Right Honourable The Lord Cooke Of Thorndon" (2008) 39 VUWLR 9.

4 Francis Cooke "A Personal Word" (2008) 39 VUWLR 15.

5 Dean Knight "Simple, Fair, and Discretionary Administrative Law" (2008) 39 VUWLR 117.

6 Elisabeth McDonald "Going "Straight to Basics": The Role of Lord Cooke in Reforming the Rule Against Hearsay - from Baker to the Evidence Act 2006" (2008) 39 VUWLR 143.

7 Susy Frankel "Lord Cooke and Patents: The Scope of 'Invention"' (2008) 39 VUWLR 97. 
Three other articles, in the areas of human rights, ${ }^{8}$ the Treaty of Waitangi, ${ }^{9}$ and equity, ${ }^{10}$ comment, inter alia, on Lord Cooke's view on the role of the judiciary. As already indicated by Susy Frankel in regard to patent law, Lord Cooke saw distinct tasks for the legislature and the judiciary. Even though judges were to make "worthwhile contribution[s] ...towards the evolution of more just national and international societies"11 judges were not to usurp Parliament's power of law making. Therefore, in some areas of New Zealand law, despite them having had the benefit of Lord Cooke's forward thinking and sensitive analysis, law makers are asked to make necessary changes and lead the way. ${ }^{12}$

Lord Cooke occupied an office on the first floor of the Old Government Buildings which he readily used. His Lordship took regularly part in the life of the Law School and was always prepared to engage with students and staff by giving guest lectures, judging competitions, and just chatting in the corridor. He is thoroughly missed.

A special thank you to Melanie Smith, the VUWLR Editorial Committee, and Jack Wass, Student Editor-in-Chief, for their help in making this issue possible.

Petra Butler

Wellington, April 2008

8 Justice Michael Kirby "Robin Cooke, Human Rights and the Pacific Dimension" (2008) 39 VUWLR 119.

9 Paul McHugh "'Treaty Principles': Constitutional Relations Inside a Conservative Jurisprudence" (2008) 39 VUWLR 39

10 Andrew Butler "Simplicity and Innovation in the Law of Equity and Trusts: the Cooke Era" (2008) 39 VUWLR 167.

11 Robin Cooke "Sketch from the Blue Train" [1994] NZLJ 10, 17.

12 See McHugh, above n 10 and Butler, above n 11 . 